\title{
Joggyakorlat
}

\author{
BÁNYAI ORSOLYA*
}

\section{Egy elszalasztott lehetőség: a hágai Nemzetközi Bíróság ítélete Nicaragua és Costa Rica környezetvédelmi vonatkozású jogvitájában}

\author{
nemzetközi környezetjog - Nemzetközi Bíróság - Nicaragua és Costa Rica - \\ környezeti hatásvizsgálat
}

\begin{abstract}
A hágai Nemzetközi Bíróság (a továbbiakban: Bíróság) 2015. december 16-án hozta meg ítéletét ${ }^{1}$ a Nicaragua által határ menti területeken végzett bizonyos tevékenységek (Costa Rica v. Nicaragua) és a San Juan folyó mellett épülő út ügyében (Nicaragua v. Costa Rica). Az eset egyike volt a napjainkban az ENSZ bírói fóruma előtt folyó környezetvédelmi vonatkozású jogvitáknak. A szakirodalomban nagy várakozásokkal tekintettek rá, kíváncsiak voltak arra, hogy a hágai testület az Uruguay folyón épített papírmalom, ${ }^{2}$ illetve az antarktiszi bálnavadászat ügyében ${ }^{3}$ hozott ítéletek után, a peres felek által előterjesztett, környezetvédelemmel kapcsolatos kérdésekben hogyan foglal állást. Az alábbiakban én is az ítélet azon részeinek a bemutatására és értékelésére helyezem a hangsúlyt, amelyek a környezetvédelemhez kapcsolhatók. A tanulmány első három pontjában az ügy alapjául szolgáló tényeket, a pertörténetet, a jogi érvelés menetét és a konkrét döntéseket ismertetem, míg az ítélettel kapcsolatos meglátásaimat a jogi érvelés kritikájában, illetve az ügy jelentőségével kapcsolatos részben fogalmazom meg.
\end{abstract}

* Dr. Bányai Orsolya egyetemi adjunktus, Debreceni Egyetem Állam- és Jogtudományi Kar Agrárjogi, Környezetjogi és Munkajogi Tanszék, banyai.orsolya@law.unideb.hu.

1 Case concerning Certain Activities Carried out by Nicaragua in the Border Area (Costa Rica v. Nicaragua) Proceedings Joined with Construction of a Road in Costa Rica along the San Juan River (Nicaragua v. Costa Rica) on 17 April 2013., Judgment of 16 December 2015 (a továbbiakban: Costa Rica v. Nicaragua ügyben hozott itélet).

2 Case Concerning Pulp Mills on the River Uruguay (Argentina v. Uruguay), Judgment of 20 April 2010, ICJ Reports 2010.

3 Whaling in the Antarctic (Australia v. Japan: New Zealand intervening), Judgment of 31 March 2014. 


\section{Tények}

2010. október 18-án Nicaragua a San Juan folyó hajózhatóságának fejlesztése érdekében kotrási műveletekbe kezdett, és hasonló munkálatokba kezdett az Isla Portillos és a San Juan folyó torkolata közötti területen is. Nicaragua elmondása szerint a munkálatok egy már létező csatorna tisztítását szolgálták, ezzel szemben Costa Rica úgy vélte, hogy Nicaragua egy mesterséges csatornát (cano) épít Costa Rica területén. ${ }^{4}$ Nicaragua haderőt vezényelt az érintett területre.

2010 decemberében Costa Rica megkezdte az 1856-os Juan Rafael Mora Porras út (a továbbiakban: az út) kiépítését, amely Costa Rica területén halad a nicaraguai határ mentén, tervezett hossza pedig közel $160 \mathrm{~km}$. Egy 2011. február 21-én elfogadott rendelettel az út építését, szükséghelyzetre hivatkozva, mentesítették az előzetes környezeti hatásvizsgálati kötelezettség alól.

A per előzményéhez tartozik az is, hogy a Bíróság korábban már eljárt a két ország ügyében. Ennek során egyértelmúvé tette Costa Rica hajózási jogát a San Juan folyón, illetve rögzítette Nicaragua jogát a folyó szabályozására (Costa Rica v. Nicaragua, 2009)..$^{5}$

\section{Pertörténet}

Costa Rica 2010. november 18-án eljárást kezdeményezett Nicaragua ellen (Costa Rica v. Nicaragua). Keresetlevelében azt kérte a Bíróságtól, hogy mondja ki: Nicaragua megsértette Costa Rica területi integritását, komoly károkat okozott védett esőerdőiben és vizes élöhelyein, továbbá kotrási munkálatokkal veszélyeztette a San Juan folyó flóráját és faunáját. Jogalapként - többek között - a két ország közötti 1858-as határegyezményt, az ENSZ Alapokmányban lefektetett nemzetközi jogi alapelveket, valamint a ramsari egyezményt ${ }^{6}$ jelölte meg. Arra kérte a hágai testületet, hogy döntsön a kártérítés és helyreállítás kérdésében is. Costa Rica a kereset benyújtásának napján ideiglenes intézkedés meghozatalát is kezdeményezte,

${ }_{4}$ Raisz Anikó leírja az ügy egyik nem elhanyagolható hátterét is: Nicaragua egy, a Panama-csatornához hasonló, kontinenst átszelő csatornát akar építeni. RAIsz Anikó: A nemzetközi környezetvédelmi bíráskodás jelene és jövője. In: Collegium Doctorum. Miskolc, 2012, 3-4.

5 Case concerning the Dispute Regarding Navigational and Related Rights (Costa Rica v. Nicaragua), Judgment (13 July 2009) ICJ General List No. 133. Ezen ügy érintettségét Raisz Anikó már 2011-ben elöre jelezte. RAIsz Anikó: Nemzetközi környezetvédelmi kérdések a Nemzetközi Bíróság elött napjainkban. Publicationes Universitatis Miskolciensis, Sectio Juridica et Politica, Tom. XXIX./1., 2011, 284. A 2009-es ügyröl lásd még BARKER, Craig: International Court of Justice, Case concerning the dispute regarding navigational and related rights (Costa Rica v. Nicaragua) Judgment of 13 July 2009. International and Comparative Law Quarterly, 2011/1, 271-279.

6 Egyezmény a nemzetközi jelentőségủ vizes területekröl (Ramsar, 1971. február 2.). Kihirdette: 1993. évi XLII. törvény a nemzetközi jelentőségü vadvizekröl, különösen mint a vízimadarak tartózkodási helyéröl szóló, Ramsarban, 1971. február 2-án elfogadott egyezmény és annak 1982. december 3-án és 1987. május 28.-június 3. között elfogadott módosításai egységes szerkezetben történő kihirdetéséröl. 
amelynek a Bíróság 2011. március 8-ai határozatával helyt is adott. ${ }^{7}$ Többek között elrendelte a nicaraguai csapatok visszavonását a Costa Rica-i államterületröl, illetve mindkét fél civil, katonai és biztonsági személyzetének kivonását a vitatott státuszú és hovatartozású területekröl.

Mivel a vitatott területen rendszeresen szervezett csoportok voltak jelen továbbra is, Costa Rica - a Nemzetközi Bíróság történetében elöször ${ }^{8}$ - kezdeményezte az ideiglenes intézkedés módosítását. ${ }^{9} \mathrm{~A}$ módosításra irányuló kérelem elutasítását ${ }^{10}$ követően, immár új bizonyítékok alapján egy új ideiglenes intézkedés meghozatalát kérte. ${ }^{11}$ Costa Rica ekkor már müholdfelvételekkel tudta bizonyítani, hogy Nicaragua katonai haderővel van jelen a területen, és időközben két további csatornát ásott ki. Ennek eredményeképpen a Bíróság 2013. november 23-án megerősítette és kiegészítette a 2011-ben elrendelt ideiglenes intézkedését. Ebben arra kötelezte Nicaraguát, hogy tartózkodjon minden kotrási müvelettöl a vitatott területen, töltse fel az árkot a tengerparton a keleti csatorna (cano) északi részénél; minden személyt távolítson el a területröl, függetlenül attól, hogy civilekröl, katonákról vagy biztonsági személyzetről van szó, illetve a továbbiakban akadályozza meg ilyen személyzet belépését a vitatott területre. ${ }^{12}$

2011. december 22-én Nicaragua is keresettel fordult a Bírósághoz (Nicaragua v. Costa Rica), amelyben a felperes annak megállapítását kérte a Bíróságtól, hogy Costa Rica a San Juan folyó mentén végzett útépítési munkálataival megsértette területi integritását, jelentős környezeti károkat okozva számára. Nicaragua kötelezné Costa Ricát az építkezési munkálatok befejezésére és az eredeti állapot helyreállitására, kártérítésért is folyamodott, valamint kérte minden jövőbeli fejlesztés megtiltását a területen, megfelelő nemzetközi környezeti hatásvizsgálat lefolytatása hiányában. Jogalapként Nicaragua is a két ország közötti 1858-as határegyezményre, valamint nemzetközi környezetvédelmi egyezményekre (például a ramsari egyezmény, ENSZ Biológiai Sokféleség Egyezmény) hivatkozott. A két ügyben zajló eljárást a Bíróság 2013. április 17-én egyesítette, majd 2015. december 16-án hozta meg ítéletét az ügyben.

7 Certain Activities carried out by Nicaragua in the Border Area (Costa Rica v. Nicaragua), Order of 8 March 2011, ICJ Reports 2011.

8 Lamus, Andrés Sarmiento: Revocation and Modification of Provisional Measures in the International Court of Justice: The Court's Order regarding Activities Carried out by Nicaragua in the Border Area and the Case concerning Construction of a Road in Costa Rica along the San Juan River joint proceedings. The Law of Practice of International Courts and Tribunals, 2013/12, 464.

9 Request by Costa Rica for the Modification of the Court's Order of 8 March 2011 (23 May 2013). Ehhez hozzátartozik, hogy Nicaragua is kezdeményezte az ideiglenes intézkedés módosítását, az útépítésből eredő károk csökkentése érdekében.

10 Certain Activities Carried out by Nicaragua in the Border Area (Costa Rica v. Nicaragua); Construction of a Road in Costa Rica along the San Juan River (Nicaragua v. Costa Rica), Order of 16 July 2013, Provisional Measures, ICJ Reports 2013, 230.

11 Request by Costa Rica for the Indication of New Provisional Measures in the Costa Rica v. Nicaragua Case, 23 September 2013.

12 Certain Activities Carried out by Nicaragua in the Border Area (Costa Rica v. Nicaragua); Construction of a Road in Costa Rica along the San Juan River (Nicaragua v. Costa Rica), Provisional Measures, Order of 22 November 2013, ICJ Reports 2013, 354, 59. 


\section{A döntés jogi érvelésének rekonstrukciója}

\subsection{Costa Rica v. Nicaragua ügy}

A Costa Rica v. Nicaragua ügy kapcsán a Bíróság a felmerülő jogi kérdéseket öt részletben tárgyalta: a) a vitatott terület melyik állam szuverenitása alá tartozik, illetve a szuverenitás megsértése; $b$ ) a nemzetközi környezetvédelmi jog megsértése; c) az ideiglenes intézkedések megsértése; $d$ ) hajózási jogok; e) és végül a kártérítés. Az alábbiakban ezek közül érintölegesen foglalkozom az a), c) és e) pontokkal, részletesebben azonban csak $a b$ ) ponttal, ugyanis ennek van jelentösebb környezetvédelmi vonatkozása.

Mielött rátérnék a nemzetközi környezetvédelmi jogsértés megítélésére, meg kell említenem, hogy a hágai testület először arra törekedett, hogy tisztázza Costa Rica területi szuverenitásának állítólagos megsértését. A Bíróság a két ország közötti 1858-as határegyezmény és a felek által benyújtott bizonyítékok alapján arra jutott, hogy a kérdéses, kb. $3 \mathrm{~km}^{2}$ terület (Isla Portillos) Costa Ricához tartozik, és Nicaragua azzal, hogy 2010 óta három csatornát ásott és katonai erőket küldött a területre, megsértette Costa Rica szuverenitását. Nicaragua ezért a Bíróság szerint felelősséggel tartozik, és a vagyoni, illetve nemvagyoni károk megtérítésére köteles (ennek összegét a Bíróság első körben a felek közötti tárgyalásokra bízta). ${ }^{13}$ Ezenfelül a testület azt is megállapította, hogy Nicaragua a második és harmadik csatorna kiásásával, valamint a vitatott területen (Isla Portillos) a katonai jelenlétének fenntartásával megsértette a Bíróság 2011-es ideiglenes intézkedését is. ${ }^{14}$

Ami a nemzetközi környezetvédelmi jog megsértését illeti, a Bíróság Costa Rica környezetvédelmi vonatkozású követeléseit két részre osztotta. Az egyik formális, eljárásjogi természetű: Nicaragua megsértette azt a kötelezettségét, hogy nemzetközi környezeti hatásvizsgálatot folytasson le a kotrási munkálatok kapcsán, valamint ezekről értesítse Costa Ricát és érdemben konzultáljon vele. A másik anyagi jogi természetü: Nicaragua környezetvédelmi kötelezettséget sértett, amikor kárt okozott Costa Rica területén. Az alábbiakban a megállapítások mentén mutatom be a két kérdéskört.

${ }_{13}$ A Bíróság elutasította Costa Rica azon követelését, miszerint Nicaraguára terhelje azokat az eljárási költségeket, amelyek a 2013-as ideiglenes intézkedés kezdeményezésével függnek össze, azon az alapon, hogy fö szabály szerint minden költséget a felek viselnek az eljárásban. Tomka, Greenwood, Sebutinde és Dugard bírók különvéleményükben azonban ezt kifogásolják. Véleményük szerint az ügy körülményei alapján Nicaraguára kellett volna ezeket a költségeket terhelni, még akkor is, ha ezzel - az egyébként a Statútum 64. cikkében biztosított - lehetőséggel a Bíróság eddig még sohasem élt.

14 A Nemzetközi Bíróság szerint Nicaragua a 2013. november 22-én kelt ideiglenes intézkedéshez már tartotta magát, azt nem sértette meg. 


\subsubsection{A környezeti hatásvizsgálat elmaradásáró/15}

A Bíróság kiindulópontja e tekintetben az Uruguay folyón épített papírmalom ügyében hozott ítélet volt (Uruguay v. Argentína, 2010). ${ }^{16}$ Ebben megállapította, hogy az általános nemzetközi jog szerint minden olyan beruházás megvalósítása elött, amely jelentős, határokon átívelő kárral fenyeget, környezeti hatásvizsgálati eljárást kell lefolytatni. Érdemes kiemelnem, hogy ennek a kötelezettségnek a deklarálása ebben az ügyben történt meg elöször, ráadásul egy olyan vitában, ahol az alkalmazott jog (az 1975. évi Statútum) nem is követelte meg a környezeti hatásvizsgálat lefolytatását. ${ }^{17}$

Tekintettel arra, hogy mindkét fél elismerte az elöbbi szabályt, de Costa Rica elégtelennek tartotta azt a környezeti hatásvizsgálatot, amelyet Nicaragua 2006ban készített, Nicaragua szerint viszont e hatásvizsgálat megfelelő volt, így a Bíróság kiemelte: a környezeti hatásvizsgálat tartalmát mindig a konkrét ügy fényében kell meghatározni. ${ }^{18}$ Ismét visszautalt az Uruguay folyón épített papírmalom ügyére, amelyben rögzítette, hogy minden államnak magának kell a belső jogában vagy a beruházást megelőző hatósági eljárásban meghatároznia a környezeti hatásvizsgálat speciális tartalmát, tekintettel a beruházás természetére, nagyságára, különféle várható hatásaira, valamint elvárható gondossággal (due diligence) kell eljárnia annak lebonyolításában. Amennyiben a hatásvizsgálat eredménye szerint jelentős, határon átterjedő környezeti hatások várhatók, úgy az államnak, jóhiszeműen eljárva, értesítenie és konzultálnia kell a másik állammal, hogy megelőzzék, illetve csökkentsék a kockázatot. ${ }^{19}$

Ezt követően a Bíróság azt vizsgálta, hogy a kotrási műveleteknek jelentős, határon is átnyúló hatásai vannak-e. A Nicaragua által lefolytatott 2006-os környezeti hatásvizsgálat szerint a munkáknak nem lesz határon átnyúló hatása, illetve nem fogják jelentősen megváltoztatni a Colorado folyó áramlását. ${ }^{20}$ Bár ezt a megállapítást Costa Rica vitatta, később mindkét fél szakértői által megerősítést nyertek. Megvizsgálva a felsorakoztatott bizonyítékokat, beleértve a szakértői véleményeket

15 Costa Rica v. Nicaragua ügyben hozott itélet, 101-112. pontok.

16 Case Concerning Pulp Mills on the River Uruguay (Argentina v. Uruguay), Judgment of 20 April 2010, ICJ Reports 2010.

17 BRUHÁcs János: Argentína és Uruguay vitája: a Nemzetközi Bíróság 2010. évi ítélete az Uruguay folyó menti papírgyár ügyben. Jura, 2012/2, 48.

18 A Nicaragua által 2006-ban készített környezeti hatástanulmány arra a megállapításra jutott, hogy a kotrási műveletek nem lesznek káros hatással a Colorado folyó áramlására. Costa Rica azonban ezt kétkedve fogadta, valamint hozzátette, hogy a 2006-os hatástanulmány a munkálatoknak a vizes élőhelyekre gyakorolt hatását sem vizsgálta, holott a Ramsar Tanácsadó Küldöttség 2011-es jelentésében megerősítette a határon átnyúló káros hatások veszélyét. Nicaragua szerint ez csak egy jelentéstervezet volt, amelyet a Ramsar Titkárság sohasem véglegesített, és már annak idején is rámutatott ennek a megállapításnak a helytelenségére. Costa Rica v. Nicaragua ügyben hozott ítélet, 102-103. pontok.

19 Costa Rica v. Nicaragua ügyben hozott ítélet, 104. pont.

20 A San Juan folyó a Nicaragua-tótól indulva a Karib-tengerbe fut. Mielőtt elérné a tengert, egy ponton (ez az ún. Delta Colorado) két ágra válik szét. Az egyik ága a San Juan folyó alsó szakasza néven ismert (itt zajlottak a kotrási múveletek); míg a másik a Colorado folyó, amely már Costa Rica területén található. Costa Rica v. Nicaragua ügyben hozott ítélet, 56. pont. 
is, a Bíróság végül arra a megállapításra jutott, hogy a munkálatoknak nem lesz jelentős, határon átívelő környezeti hatása, ezért Nicaraguának nem kötelessége a környezeti hatásvizsgálat lefolytatása. ${ }^{21}$

A testület ezután Nicaragua értesítési és konzultációs kötelezettségének vizsgálatával foglalkozott. ${ }^{22}$ Ezzel kapcsolatban felelevenítette Costa Rica érveit, miszerint a nemzetközi jelentőségü vadvizekröl szóló ramsari egyezmény 3. cikkének (2) bekezdése, valamint az egyezmény 5 . cikke alapján Nicaraguát értesítési és konzultációs kötelezettség terheli a kotrási műveletek vonatkozásában. Nicaragua szerint, bár az értesítési és konzultációs kötelezettség az általános nemzetközi jogban fennáll, alkalmazhatóságát a konkrét ügyben a két ország közötti 1858-as határegyezmény, mint lex specialis, korlátozta. A határegyezmény ugyanis semmilyen notifikációs, konzultációs vagy egyéb eljárási kötelezettséget nem tartalmaz semmilyen fejlesztési munka tekintetében, továbbá a nemzetközi szokásjog, illetve a nemzetközi szerződések jogában fellelhető hasonló természetű kötelezettségek sem alkalmazhatók véleménye szerint a konkrét ügyben. Ha mégis, úgy arra az esetre Nicaragua azt emelte ki, hogy a kotrási munkálatoknak a bizonyítékok alapján nincs jelentős, határon átterjedő hatása.

A hágai testület szerint az a tény, hogy az 1858-as határegyezmény semmilyen notifikációs és konzultációs kötelezettséget nem tartalmaz, még nem mentesítené eljárásjogi kötelezettségei alól Nicaraguát, ha a San Juan folyón végzett munkálatoknak jelentős, határon átívelö környezeti hatása lenne. Mindenesetre megállapította, hogy jelentős, határon átívelő környezeti kár kockázatának hiányában Nicaraguát értesítési és konzultációs kötelezettség sem terhelte Costa Rica vonatkozásában.

A Bíróság azt is rögzítette, hogy mindkét ország részese a ramsari egyezménynek, amelynek a 3. cikk (2) bekezdése alapján a feleket értesítési kötelezettség terheli. A hágai testület álláspontja szerint azonban ez az értesítési kötelezettség csak a Ramsar Titkárság irányában áll fenn, és csak abban az esetben, ha a „vizes élőhely ökológiai jellege megváltozott”. Jelen esetben a Bíróság előtt fekvő bizonyítékok azonban ezt nem támasztják alá, ezért Nicaraguának nem kellett értesítenie a titkárságot. Ami a ramsari egyezmény 5 . cikkét illeti, a Bíróság szerint ez egy általános együttmüködési kötelezettséget tartalmaz az egyezményböl eredő kötelezettségek végrehajtásával kapcsolatban, ami Nicaragua számára nem teremt a konkrét projekt vonatkozásában konzultációs kötelezettséget. Tehát a ramsari egyezmény alapján Nicaraguát semmilyen értesitési és együttmüködési kötelezettség nem terhelte, mielött hozzálátott a kotrási munkákhoz. Összességében tehát a Bíróság úgy találta, hogy a nemzetközi környezetvédelmi szokásjog és szerződések joga alapján Nicaragua nem sértett eljárásjogi szabályokat. ${ }^{23}$

A Bíróság tehát a környezeti hatásvizsgálati kötelezettség elmaradásának megítélésénél a következő gondolatmenetet követte: mindenekelőtt felidézte a kapcsolódó szokásjogot, majd megvizsgálta azt a kulcskérdést, hogy a határon átnyúló hatások ebben az esetben jelentősek-e, majd Nicaragua értesítési és konzultációs

21 Costa Rica v. Nicaragua ügyben hozott itélet, 105. pont.

22 Costa Rica v. Nicaragua ügyben hozott ítélet, 106-111. pontok.

23 Costa Rica v. Nicaragua ügyben hozott ítélet, 112. pont. 
kötelezettségét elemezte a szokásjog, illetve a ramsari egyezmény alapján, és arra jutott, hogy a nemzetközi környezetvédelmi szokásjog és szerződések joga alapján Nicaragua nem sértett eljárásjogi szabályokat.

\subsubsection{A határon átívelő károkozásról}

A hágai testület e körben mindenekelött elkülönítette egymástól azokat a tevékenységeket, amelyeket Nicaragua a saját, illetve Costa Rica-i (Isla Portillos) területen végzett. Ez utóbbi vonatkozásában a Bíróság már az ítélet $A$ ) pontjában megállapította, hogy Nicaragua felelős azokért a károkért, amelyeket Costa Rica területi szuverenitásának megsértésével okozott. Az ítéletnek ebben a részében lényegében már csak annak a tisztázása maradt hátra, hogy felelős-e Nicaragua azokért a károkért is, amelyek állitólag a San Juan folyó alsó szakaszán, a saját államterületén végzett kotrási müveletekből származnak.

A Bíróság felelevenítette a Trail Smelter itélet ${ }^{24}$ óta klasszikusnak tekinthető nemzetközi jogi szabályt, miszerint egy állam csak úgy használhatja saját erőforrásait, hogy azzal nem okoz jelentős környezeti kárt a másik állam területén. ${ }^{25}$

A Bíróság megemlítette, hogy mindkét ország hivatkozott az 1858-as határegyezményre, amelyet azonban eltérően értelmeznek. Nicaragua szerint a határegyezményböl az következik, hogy akkor is joga van kotrási munkák végzésére, ha azok egyébként károsak Costa Ricának. Costa Rica azonban úgy látja, hogy a határegyezmény alapján, ha Nicaragua bármilyen (és nemcsak jelentős) kárt okoz Costa Ricának, úgy azért kártérítéssel tartozik. Továbbá úgy véli, hogy a határegyezményt a nemzetközi környezetvédelmi szokásjoggal összhangban kell értelmezni, amely tiltja a jelentős, határon átnyúló károkozást.

A testület átugrotta azt a kérdést, hogy hogyan viszonyul egymáshoz a két ország közötti határegyezmény és a nemzetközi környezetvédelmi szokásjog, ugyanis csak annyit állapított meg, hogy Costa Rica nem tudott bizonyítékot bemutatni olyan károkat tekintve, amelyek a területén történtek (például üledéklerakódás a folyó jobb partján). A 2011. január és 2014. október közötti időszakban jelentősen csökkent a Colorado folyó vízhozama, azonban Costa Rica nem tudta bizonyítani a kotrási munkák és a vízhozam változása közötti okozati összefüggést, valamint ő maga is elismerte, hogy ehhez más tényezők is hozzájárulhattak, mint például a szokatlanul kevés csapadék. ${ }^{26}$

Az ENSZ legfelsőbb bírói fóruma végül megállapította, hogy nincs elfogadható bizonyíték arra, hogy Nicaragua kárt okozott volna Costa Ricának a saját területén, a San Juan folyó alsó szakaszán végzett kotrási munkálatokkal.

24 Trail Smelter Case (United States v. Canada), Reports of International Arbitral Awards, 16 April 1938 and 11 March 1941, Vol. III., 1905-1982.

25 Costa Rica v. Nicaragua ügyben hozott itélet, 118. pont.

26 Costa Rica v. Nicaragua ügyben hozott ítélet, 119. pont. 


\subsection{A Nicaragua v. Costa Rica ügy}

A Nicaragua v. Costa Rica ügyet a Nemzetközi Bíróság három részre bontva elemezte: eljárásjogi jellegü jogsértések, anyagi jogi jogsértések és kártérítés.

\subsubsection{Eljárásjogi jellegü jogsértések}

Az eljárásjogi jellegű jogsértések kapcsán a Bíróság lényegében a környezeti hatásvizsgálat lefolytatásának kötelezettségét, illetve a tájékoztatási és konzultációs kötelezettséget vizsgálta.

Először is felidézte a felek érveit. Nicaragua szerint Costa Rica megsértette a nemzetközi jogot, amikor úgy kezdte meg az út építését, hogy elötte nem végzett környezeti hatásvizsgálatot. Costa Rica tagadta mindezt. Álláspontja szerint az útépítésnek nincsenek jelentős, határon átnyúló környezeti hatásai, ráadásul állami szükséghelyzet okán (amit Nicaragua okozott az Isla Portillos megszállásával) kivételesen nem is kellett volna hatásvizsgálatot lefolytatnia. Ezt véleménye szerint a nemzetközi jog lehetővé teszi, ráadásul az útépítés megfelelő válasz volt ebben a szükséghelyzetben, mivel megkönnyítette a rendőrségi állomáshelyek, az elszigetelt települések megközelítését, illetve a megszállt terület evakuálását. Arra az esetre, ha mégis kötelessége lett volna a környezeti hatásvizsgálat, elmondása szerint erre 2013-ban sort kerített. Nicaragua szerint Costa Rica nem jóhiszeműen hivatkozott a szükséghelyzetre, mivel az út távol esik az elfoglalt területtöl, az építését már néhány hónappal a szükséghelyzet kihirdetése előtt megkezdték, ráadásul a nemzetközi jog nem is ismer ilyen jellegü kivételt a hatásvizsgálati kötelezettség alól. Ami pedig a 2013-as hatástanulmányt illeti, Costa Rica azt már azt követően készítette, hogy az útépítési munkák jelentős része befejeződött.

A Bíróság mindenekelőtt azt a kérdést vizsgálta, hogy szükséges-e környezeti hatásvizsgálat lefolytatása, majd csak ezt követően foglalkozott azzal, hogy van-e ez alól kivétel, illetve a 2013-as hatástanulmány vagy más hasonló tanulmány megfelelt-e erre a célra. Ismételten rögzítette, hogy a nemzetközi jogban szokásjogi erővel bír az a szabály, miszerint minden olyan beruházás megvalósítása előtt, amely jelentős, határokon átívelő kárral fenyeget, környezeti hatásvizsgálati eljárást kell lefolytatni.

Ezt követően megvizsgálta az útépítés környezetre gyakorolt hatásának jelentőségét. Ennek során úgy vélte, hogy az útépítés sokkal jelentősebb beruházás, mint azt Costa Rica állította. 160 km hosszú útról van szó, amelyből 108 km a San Juan folyó mentén halad, s több mint a fele teljesen újonnan épül. Továbbá az út nagyon közel (esetenként mindössze 5 méterre) fut a Nicaragua területéhez tartozó folyóhoz, ráadásul gyakran lejtős részeken halad, ami megnöveli az üledék bemosódásának (szedimentáció) kockázatát. Ezt a kockázatot ráadásul tovább növeli az a tény, hogy az út fele eredetileg erdős területen halad, s így a talajerózió tovább növeli a szedimentáció valószínüségét. Végezetül figyelembe kell venni, hogy az út áthalad egy védett természeti területen, amelyhez nagyon közel található (Nicaragua területén) egy másik vadvízi élőhely is (Refugio de Vida Silvestre Río San Juan). Ez a tény jól jelzi az érintett terület fokozott érzékenységét. Minderre tekintettel a Bíróság 
megállapította, hogy az út várhatóan jelentös, határon átívelö környezeti hatással jár, ennélfogva környezeti hatásvizsgálat lefolytatására kellett volna hogy sor kerüljön. ${ }^{27}$

A Bíróság áttért arra a kérdésre, hogy szükséghelyzet mentesíti-e Costa Ricát az útépítés várható környezeti hatásainak feltérképezése alól. Ennek kapcsán elöször újból felidézte az Uruguay folyón épített papírmalom ügyét, amelyböl kiemelte, hogy minden államnak magának kell a belső jogában vagy a beruházást megelőző hatósági eljárásban meghatározni a környezeti hatásvizsgálat speciális tartalmát. A Bíróság megjegyzése szerint ez a belső jogra való hivatkozás nem kapcsolódik ahhoz a kérdéshez, hogy kell(ett)-e környezeti hatásvizsgálatot lefolytatni. Így az a tény, miszerint létezik egy szükséghelyzettel kapcsolatos kivétel Costa Rica belső jogában, nem befolyásolja Costa Rica nemzetközi jogon alapuló kötelezettségét a környezeti hatásvizsgálat lefolytatására.

Továbbá attól függetlenül, hogy a szükséghelyzet mentesíthet-e vagy sem egy államot a nemzetközi jogon alapuló környezeti hatásvizsgálat lefolytatása alól, vagy elhalaszthatja-e ennek lefolytatását a szükséghelyzet megszúnéséig, a testület a jelen ügy körülményei ismeretében úgy vélte, hogy Costa Rica nem tudta igazolni a szükséghelyzet létét, ami indokát adhatta volna a környezeti hatásvizsgálat nélkül lefolytatott útépítésnek. Amikor Costa Rica hozzálátott az útépítéshez, az ügy Nicaragua ténykedése miatt már a Bíróság előtt volt, amely röviddel ezután ideiglenes intézkedést rendelt el. Ráadásul az út csak részben biztosít kapcsolatot a Nicaragua által megszállt területtel, így az építkezés csak korlátozott mértékben lehetett válasz a szükséghelyzetre. Továbbá Costa Rica azt sem tudta igazolni, hogy azokon a területeken, ahol az út haladt, közelgő katonai konfliktus fenyegetett volna. Végezetül a Bíróság még azt is hozzátette, hogy az a végrehajtási rendelet, amelyben Costa Rica szükséghelyzetet hirdetett, azt követően került kibocsátásra, miután az út építése már megkezdődött. Mindebből azt a következtetést vonta le a Bíróság, hogy Costa Rica nem volt olyan szükséghelyzetben, ami az útépítést indokolta volna. Így a Bíróságnak arról sem kell állást foglalnia, hogy a szükséghelyzet, mint olyan vajon kivételt jelenthet-e a környezeti hatásvizsgálat lefolytatása alól. ${ }^{28}$

Ezek után következett annak a kérdésnek a tisztázása, hogy a Costa Rica által készített környezeti hatástanulmányok (például Environmental Management Plan, 2012; Environmental Diagnostic Assessment, 2013), kielégítik-e a környezeti hatásvizsgálati kötelezettséget. Ezek a tanulmányok azokat a környezeti hatásokat értékelték, amelyeket az útépítés okozott, és javaslatokat tartalmaztak e káros hatások megelőzésére, illetve enyhítésére. Ezzel kapcsolatban a Bíróság újból visszautalt az Uruguay folyón épített papirmalom ügyére, amelyben már rögzítette, hogy a környezeti hatásvizsgálati kötelezettség egy projekt kapcsán folyamatos kell hogy legyen. Vagyis biztosítani kell a beruházás környezetre gyakorolt hatásának folyamatos figyelemmel kísérését annak teljes élettartama alatt. Ugyanakkor ez egyben azt is jelenti, hogy a beruházás megkezdése előtt (ex ante) is kell környezeti hatásvizsgálatot lefolytatni. Így Costa Ricának még az útépités megkezdése elött fel kellett volna mérnie a várható környezeti kockázatokat. Azok a hatástanulmányok,

27 Costa Rica v. Nicaragua ügyben hozott ítélet, 155-156. pontok.

28 Costa Rica v. Nicaragua ügyben hozott ítélet, 158-159. pontok. 
amelyeket készített, már az útépítés megkezdése után vizsgálták az okozott környezeti károkat. Ezek tehát utólagos (post hoc) hatásvizsgálatok voltak. Ezek alapján a Bíróság megállapította, hogy Costa Rica nem teljesítette a környezeti hatásvizsgálat lefolytatásának nemzetközi jogon alapuló kötelezettségét. ${ }^{29}$

A testület az eljárási kötelezettségek megsértése kapcsán foglalkozott Costa Rica tájékoztatási és konzultációs kötelezettségével is. Ezzel kapcsolatban már az Uruguay folyón épített papírmalom ügyében kimondta, hogy amennyiben a hatásvizsgálat eredménye szerint jelentős, határon átterjedő környezeti hatások várhatók, úgy az államnak jóhiszeműen eljárva értesítenie és konzultálnia kell a hatásviselö állammal, hogy megelőzzék, illetve csökkentsék a kockázatot. Mindazonáltal, tekintve, hogy Costa Rica nem végzett ex ante környezeti hatásvizsgálatot az útépítés tekintetében, így ezt a kérdést a Bíróság szerint nem kellett vizsgálni. Megállapította továbbá, hogy Costa Ricának sem az 1858-as határegyezmény, sem a ramsari egyezmény 5 . cikke alapján nem állt fenn tájékoztatási kötelezettsége. ${ }^{30}$

Összességében tehát Costa Rica megsértette a nemzetközi jogot, amikor annak ellenére, hogy az útépités jelentős, határon átnyúló környezeti károkkal fenyegetett, nem folytatott le elözetes környezeti hatásvizsgálatot.

\subsubsection{Az anyagi jogi jogsértésröl}

Nicaragua szerint Costa Rica azzal, hogy kárt okozott a San Juan folyóban, amely az 1858-as határegyezmény szerint Nicaragua területéhez tartozik, megsértette a nemzetközi szokásjog azon szabályát, miszerint tilos jelentős kárt okozni más állam területén, és tisztelni kell más állam területi szuverenitását. Ezenfelül Nicaragua szerint Costa Rica számos nemzetközi egyezményt is megsértett.

Ami a határon átterjedő jelentős károkozást illeti, Nicaragua szerint az útépítési munkák jelentős mennyiségü üledéklerakódáshoz vezettek a San Juan folyóban. Ennek egyik okaként a talajeróziót emelte ki, amelyet az okozott, hogy az út érdekében kivágták az erdőt, így a növényzet nem tudta meggátolni a talaj bemosódását a folyóba. Szedimentációt okozott továbbá az útépítéssel járó földmozgás, valamint az is, hogy az útépítők földkupacokat hagytak szabadon az esővíznek kiszolgáltatva. $A z$ is csak rontott a helyzeten, hogy az út teljes hosszának a felében alig 100 méterre fut a folyótól, és sok helyen meredek lejtők szabdalják. Costa Rica szakértője szerint az erózió csupán egy $40 \mathrm{~km}$-es - igen meredek - útszakaszra koncentrálódik.

Nicaragua úgy vélte, hogy az üledéklerakódás csak tovább fokozza az amúgy is természetellenesen magas üledékkoncentráció mértékét a San Juan folyóban. Mivel az üledék Nicaragua szerint szennyező anyagnak minősül, így az számos kárt okoz a folyóban. Például változásokat hoz a folyó morfológiájában, az üledék lerakódik a folyómederbe, ami nehezíti annak hajózhatóságát, és további mederkotrást igényel. Az üledéklerakódás káros a víz minőségére és a folyó ökoszisztémájára is. Továbbá rossz hatással van a turizmusra, valamint a folyó melletti közösségek egészségi állapotára. További kockázatot jelenthet még mérgező anyagok vízbe

29 Costa Rica v. Nicaragua ügyben hozott ítélet, 160-162. pontok.

30 Costa Rica v. Nicaragua ügyben hozott ítélet, 165-168. pontok. 
mosódása és olyan természeti katasztrófák előfordulása, mint a földrengés, trópusi vihar vagy hurrikán.

Costa Rica szerint viszont az útépítés nem okoz kárt Nicaraguának. Véleménye szerint az erózió természetes jelenség, az üledék pedig nem szennyező anyag. Továbbá úgy látta, hogy az útépítésből adódó üledéklerakódás elenyésző a folyó üledékkoncentrációjához képest. Felhívta a figyelmet, hogy 2012-től kezdve lépéseket tett a meredek területek eróziójának csökkentésére (például a dúnék teraszos kialakításával, vízelvezető csatornák beépítésével, üledékgyűjtők kialakításával stb.). ${ }^{31}$

Mindkét fél egyetértett abban, hogy az üledék bemosódik a folyóba, de annak mértéke tekintetében eltérő állásponton voltak (Nicaragua szerint 190 000-250 000 tonna/év; Costa Rica szerint 75000 tonna/év). A Bíróság szerint ezek a számítások modellezésen, illetve becslésen alapulnak, és nem látta szükségét belemenni a technikai részletekbe. Elegendőnek tartotta megjegyezni, hogy az útépítésből adódó bemosódás a legrosszabb becslés alapján is csak a folyó terheltségének $2 \%$-át adja. $^{32}$

A hágai testület annak a kérdésnek a vizsgálatával kezdte, hogy önmagában is jelentős kárt okozott-e Nicaraguának az, hogy az útépítés hatására nőtt az üledék koncentrációja a folyóban. Majd azzal folytatta, hogy sorra vette: vajon az üledékkoncentráció növekedése kárt okozott-e a folyó morfológiájában, hajózhatóságában, a víz minőségében és a vízi élővilágban, illetve okozott-e bármilyen kárt, ami jelentősnek minösül.

A folyó üledékkoncentrációjának növekedéséböl adódó károkozással kapcsolatban ${ }^{33}$ Nicaragua gyakorlatilag azzal érvelt, hogy mivel a folyó üledékterheltsége már így is magas, ezért minden további üledékbemosódás, amely az útépítésből származik, jelentős károkozásnak minősül. Costa Rica szerint azonban, mivel az útépítésböl származó üledékbemosódás még Nicaragua számítása szerint sem több mint 2\%-a a folyó teljes terheltségének, így az nem tekinthető jelentős károkozásnak. A Bíróság végül e kérdésben Costa Rica álláspontját fogadta el. Az útépitésből származó bemosódást nem tekintette jelentősnek, figyelembe véve a folyó természetesen nagy üledékkoncentrációját, ami a régió geológiai adottságainak, illetve annak köszönhető, hogy a folyó vízgyüjtö területén földrengések és vulkánkitörések fordulnak elő. Továbbá Nicaragua azt sem tudta bizonyítani, hogy az útépítésből származó üledékbemosódás hatására a folyóban az üledék mennyisége átlépne egy kritikus szintet. Végül azt is figyelembe vette a Bíróság, hogy a San Juan folyó üledékterheltségére nézve nem létezik vízminőségi határérték, amit az útépítéssel járó üledékterhelés meghaladt volna.

A Bíróság szerint Nicaraguának nem voltak közvetlen bizonyítékai abban a tekintetben, hogy mióta az útépítés megkezdődött, megváltozott volna a folyó morfológiája. Állításai becsléseken, illetve modellezéseken alapultak, nem voltak empirikus adatok, és sok volt a tudományos bizonytalanság. ${ }^{34}$ Nem tudta bizonyítani, hogy az

\footnotetext{
Costa Rica v. Nicaragua ügyben hozott ítélet, 177-179. pontok.

Costa Rica v. Nicaragua ügyben hozott ítélet, 181-186. pontok.

Costa Rica v. Nicaragua ügyben hozott ítélet, 188-196. pontok.

34 Costa Rica v. Nicaragua ügyben hozott ítélet, 197-207. pontok.
} 
útépítés megkezdése óta fokozódott volna - az egyébként természetes jelenségnek számító - üledéklerakódás a San Juan folyó alsó szakaszán. Továbbá Nicaragua azt sem tudta bizonyítani, hogy az útépítés megkezdése óta többet kellett volna kotornia a folyó medrét, a hajózhatóság érdekében. A Bíróság szerint az útépítésből származó mintegy $2 \%$-os többletüledék nem volt jelentős káros hatással a San Juan és a Lower San Juan folyóban megfigyelhető üledéklerakódásra és Nicaragua folyókarbantartási kötelezettségeire.

A bírói testület álláspontja szerint Nicaragua azt sem tudta bizonyítani, hogy az útépítésből származó üledékbemosódás jelentős kárt okozott volna a halállományban, a mikroorganizmusokban és a víz minőségében. Az ezzel kapcsolatos bizonyítékok csak egy viszonylag kis területre vonatkoztak, amiböl viszont nem lehetett a folyó egészére nézve általánosítani. ${ }^{35}$

$A z$ egyéb lehetséges károkat (például a megnövekedett üledékkoncentráció rossz hatással van a turizmusra, valamint a folyó melletti közösségek egészségi állapotára) sem tudta bizonyítani, továbbá a Bíróság szerint a mérgező anyagok vízbe mosódásának és természeti katasztrófák előfordulásának a kockázata csupán spekuláció, tényleges károkat nem jelent.

Összességében tehát a bírói fórum arra a következtetésre jutott, hogy Costa Rica nem okozott Nicaraguának jelentős kárt. Nicaragua területi szuverenitásának, illetve nemzetközi környezetvédelmi egyezmények (például a ramsari egyezmény, a Biológiai Sokféleség Egyezmény stb.) megsértésének kérdésével lényegében nem foglalkozott, arra hivatkozva, hogy jelentős károkozás bizonyítottságának hiányában erre nincs szükség. Továbbá, mivel Costa Rica lényegében csak eljárásjogi kötelezettséget sértett, amikor nem végzett az útépités megkezdése elött környezeti hatásvizsgálatot, így a Bíróság úgy találta, hogy ez nem megfelelő alap a kártérítésre, így Nicaragua kártérítésre vonatkozó követelését elutasította. ${ }^{36}$

\section{A jogi érvelés kritikája}

A hágai testület többször visszautalt az Uruguay folyón épített papírmalom ügyére, így a nemzetközi szokásjogban a környezeti hatásvizsgálattal kapcsolatban kialakított szabályok újból megerősítésre kerültek. Az ítélet az Uruguay folyón épített papírmalom ügyében megfogalmazottakhoz képest azonban nem hoz újat, holott a Bíróságnak most a lehetősége egyértelműen adott volt erre. Bár hozzá kell tenni, hogy bizonyos kérdésekben (például értesítési és konzultációs kötelezettség jelentős környezeti hatások valószínűsége esetén) még az újbóli megerősítés is segíti a nemzetközi környezetvédelmi szokásjog kidomborítását, ugyanis maga a Bíróság sem teljesen egységes ezen kérdések megítélésében. Például Donoghue bíró kifejezetten vitatja különvéleményében, hogy az elöbb említett értesítési és konzultációs kötelezettség, abban a formában része a nemzetközi szokásjognak, ahogy azt a testület felidézte. Véleménye szerint egyáltalán nem egyértelmü, hogy az értesítési

35 Costa Rica v. Nicaragua ügyben hozott itélet, 208-213. pontok.

36 Costa Rica v. Nicaragua ügyben hozott itélet, 224-228. pontok. 
és konzultációs kötelezettség a hatások jelentőségének megállapítása után áll fenn. Az államok akkor járnak el a due diligence követelményének megfelelően, ha már a vizsgálatoknak a kezdeti szakaszába is bevonják a potenciális hatásviselö felet. Anélkül, hogy előzetesen bevonnák a hatásviselő felet, a várható hatások jelentősége és jellege sok esetben nem is becsülhető meg pontosan. ${ }^{37} \mathrm{Ez}$ a vélemény, mint azt néhány sorral alább láthatjuk majd, összecseng Dugard ad hoc bíró álláspontjával is.

A testület attól függetlenül, hogy megerősítette az alakulóban lévő szokásjogot, még iránymutatást adhatott volna néhány kérdésben. Így például arra vonatkozóan, hogy mikor tekinthető úgy egy tevékenység, hogy annak jelentős, határon átterjedő környezeti hatásai vannak. ${ }^{38}$ A Bíróság a hatások jelentőségének megítélése tekintetében egyébként aszimmetrikus helyzetbe került: Nicaragua mederkotrással kapcsolatos tevékenységei tekintetében a hatások jelentőségének mérlegelését nagyon rövidre zárta, megelégedett annak rögzítésével, hogy mindkét fél szakértői egyetértenek abban, hogy nem várható jelentős hatása a tevékenységnek. Ehhez képest a Nicaragua v. Costa Rica ügyben a hatás jelentőségének megítélése tekintetében már vállalta a bizonyítékok részletekbe menő értékelését. Ebből kiderül, hogy a jelentőség megítélésénél a Bíróság számításba vette az úttal érintett terület ökológiai érzékenységét is, tekintettel arra, hogy az egy Nicaragua területén található vadvízi élőhelyet is érint. Ezzel szemben Dugard ad hoc bíró különvéleményében rámutat, hogy a Bíróság rosszul mérlegelte a folyókotrási munkálatok hatásainak jelentőségét a Costa Rica területén található vadvízi élőhelyekre (Humedal Caribe Noreste) vonatkozóan. A bizonyítékok, amelyeket Dugard felsorakoztat, arra utalnak, hogy a hatások, különösen a terület fokozott érzékenysége miatt, jelentősek voltak. Így szerinte a környezeti hatásvizsgálat lefolytatásának kötelezettsége fennállt Nicaragua tekintetében is. Ezt követően Dugard bíró felteszi a kérdést, hogy Nicaragua vajon eleget tett-e ennek a kötelezettségnek azzal a környezeti hatástanulmánnyal, amelyet 2006-ban, még a folyókotrási munkákat megelőzően készített. A bíró véleménye szerint nemleges a válasz, mivel a 2006-os környezeti hatástanulmány, amelyet Nicaragua készített, nem tárta fel a határon átterjedő hatásokat. ${ }^{39}$ Ezzel a bíró a különvéleményében lényegében megfogalmaz egy a környezeti hatásvizsgálat tartalmával kapcsolatos alapkövetelményt is, nevezetesen, hogy tartalmazzon vizsgálatot a határon átterjedő környezeti hatások tekintetében is. Úgy tünik tehát, hogy a hágai Bíróság annak ellenére, hogy voltak bizonyítékok a Costa Rica-i vadvízi terület veszélyeztetésére (például a 2011-es ramsari jelentés), azokat rosszul mérlegelte. Ezt az is megerősíti, hogy a testület elméleti iránymutatást a hatások jelentőségének megítélésére nem adott. Ha az érintett terület fokozott érzékenysége

37 Donoghue bíró különvéleménye, 20-22. pontok.

38 Desierto, Diane: Evidence but not Empiricism? Environmental Impact Assessments at the International Court of Justice in Certain Activities Carried Out by Nicaragua in the Border Area (Costa Rica v. Nicaragua) and Construction of a Road in Costa Rica Along the San Juan River (Nicaragua v. Costa Rica), http://www. ejiltalk.org/evidence-but-not-empiricism-environmental-impact-assessments-at-the-international-court-ofjustice-in-certain-activities-carried-out-by-nicaragua-in-the-border-area-costa-rica-v-nicaragua-and-con/ (2016. 06. 22.).

39 Dugard bíró különvéleménye, 35. pont. 
ilyen körülmény lenne, úgy azt következetesen mindkét esetben alkalmaznia kellett volna. Ettöl függetlenül, úgy gondolom, hogy Nicaragua jogsértését a környezeti hatásvizsgálati kötelezettség elmulasztása miatt, az elővigyázatosság elve alapján is ki lehetett volna mondani. Ennek alapján ugyanis, a tudományosan nehezen bizonyítható, eshetölegesen jelentős negatív hatások esetén is megállná a helyét a környezeti hatásvizsgálat lefolytatásának kötelezettsége. Azért is érthetetlen a Bíróságnak ez a passzív hozzáállása, mivel itt "csupán” egy eljárási kötelezettségről volt szó, ezért a kiterjesztő értelmezés nem róna aránytalan terheket az államokra, és inkább igazodna a környezetvédelem fejlödési irányaihoz. Éppen ebből adódóan a magam részéről sajnálatosnak tartom, hogy a Bíróság ennyire nehézkesen halad elöre ennek a kötelezettségnek a tisztázásában. Ugyanakkor a jogintézmény érvényesülését csak tovább nehezíti a Bíróság, amikor úgy ítéli meg, hogy önmagában a környezeti hatásvizsgálati kötelezettség, valamint az ezzel együtt járó tájékoztatási és konzultációs kötelezettség elmaradása nem képezi megfelelő alapját a kártérítésnek. Ezzel a megközelítéssel a Bíróság maga teszi súlytalanná a nemzetközi szokásjogba beépült környezeti hatásvizsgálati követelményt. Márpedig annak elvégzése kétségtelenül jobban szolgálja a környezetvédelem legfontosabb elvét, a megelözést, mint a hatásvizsgálat elmaradása.

Ez a fajta megszorító értelmezés az ítéletben visszaköszön a ramsari egyezmény 3. és 5. cikkének értelmezése tekintetében is, holott az egyezmény szövege akár a szélesebb értelmezést is lehetővé tette volna. Ezt a gondolatot John Dugard ad hoc bíró is megerősíti különvéleményében. Véleménye szerint Nicaragua nemcsak környezeti hatásvizsgálati kötelezettségének nem tett eleget, de a ramsari egyezmény 5. cikk (1) bekezdése alapján tájékoztatási és együttműködési kötelezettségének sem. A Bíróság szerint a ramsari egyezménynek az előbb hivatkozott rendelkezése egy általános együttmüködési kötelezettséget tartalmaz csupán az egyezményböl eredő kötelezettségek végrehajtásával kapcsolatban, ami Nicaragua számára nem teremt a konkrét projekt vonatkozásában konzultációs kötelezettséget. ${ }^{40}$ Dugard ad hoc bíró szerint azonban, ha a ramsari egyezmény 5. cikk (1) bekezdését és a 3 . cikk (1) bekezdését együtt értelmezzük, úgy más következtetésre juthatunk. Az a kötelezettség, miszerint úgy kell a terveket felvázolni és megvalósítani, hogy elösegítsék a vadvízi élőhelyek megóvását, az valamennyi, a jegyzékben található vadvízi élöhelyre vonatkozik, tehát a határon túli vadvizekre is. Vagyis amikor Nicaragua 2006-ban eltervezte a folyókotrási műveleteket, és ezzel kapcsolatban környezeti hatástanulmányt készített, az ezzel kapcsolatos terveit úgy kellett volna „felvázolnia és megvalósítania", ${ }^{41}$ hogy nemcsak a saját területén található vadvízi élőhely (Refugio de Vida Silvestre Río San Juan), hanem a Costa Rica területén található élőhely (Humedal Caribe Noreste) megóvását is elösegítse. Tehát Nicaraguának annak érdekében, hogy megóvja ezeket a vadvízi élöhelyeket, konzultálnia kellett

40 Costa Rica v. Nicaragua ügyben hozott itélet, 110. pont.

$41 \mathrm{Az}$, hogy a Szerződő Felekre pontosan milyen terhet is ró ez a kötelezettség, az bizonytalan, viszont annyit biztosan, hogy meg kell előzni a más államok területén található vadvízi élőhelyek jelentős károsítását. Bowman, Michael-Davies, Peter-Redgwell, Catherine: Lyster's International Wildlife Law. Cambridge University Press, Cambridge, 2010, 424. 
volna Costa Ricával. Ez magában foglalja a környezeti hatásvizsgálat lefolytatását is. Nicaraguának a hatékony konzultáció keretében legalább egy kivonatot kellett volna adnia Costa Ricának a 2006-os környezeti hatástanulmányból, illetve meg kellett volna várnia annak észrevételeit, és csak ezt követően véglegesítenie a saját terveit. Ezen az alapon egyébként Costa Rica is megsértette a ramsari egyezmény 5. cikk (1) bekezdését, amikor nem értesítette és egyeztetett Nicaraguával az útépítés megkezdésekor. Összességében tehát Dugard bíró véleménye szerint a Bíróság tévedett, amikor kimondta: ${ }^{42}$ a ramsari egyezmény alapján fennálló konzultációs kötelezettség csak akkor lép életbe, ha jelentős, határon átterjedő kár veszélye bizonyított. ${ }^{43}$

Dugard ad hoc bíró véleményét, illetve azt a gondolatot, miszerint a ramsari egyezmény hivatkozott rendelkezéseit szélesebben is lehetett volna értelmezni, alátámasztja a ramsari egyezményben részes államok konferenciájának egyik határozata is. Ez a ramsari egyezmény 3 . cikkével összefüggésben arra ösztönzi a részes feleket, hogy minden olyan terv vagy beruházás elött folytassanak le környezeti hatásvizsgálatot, ami potenciálisan megváltoztathatja egy vadvízi élőhely ökológiai állapotát, vagy negatív hatást gyakorolhat arra ${ }^{44}$ Mint láthatjuk, itt a határozat egyáltalán nem tesz említést sem jelentős hatásról, sem a negatív hatás bizonyítottságáról. Inkább arra utal, hogyha negatív hatás várható, akár csak eshetőlegesen is (tehát nem egyértelmüen bizonyithatóan), úgy folytassanak le környezeti hatásvizsgálatot. E határozat továbbá arra is ösztönöz, hogy a hatásvizsgálat tekintetében érvényesüljön a társadalmi részvétel és nyilvánosság elve, valamint a szomszédos államok együttmüködése..$^{45}$

A Bíróság ezzel szemben, mint láthattuk, a ramsari egyezménynek mind a 3 . cikkét, mind az 5. cikkét csak bizonyíthatóan jelentős, határon átterjedő kár veszélye esetén látja alkalmazhatónak. Kimondhatta volna, hogy ha egy vadvízi terület ökológiai rendszerében akár csak eshetőlegesen is (jelentős) változás következik be, úgy a feleknek együtt kell müködniük. Az elővigyázatosság elvét ez szolgálta volna. Nem ez történt.

Ezenfelül továbbra is tisztázatlan maradt egy ehhez közvetetten kapcsolódó kérdés, miszerint lehet-e az olyan nemzetközi egyezményeket, mint a ramsari egyezmény, a felek konferenciája által megfogalmazott ajánlások figyelembevételével értelmezni. ${ }^{46}$ Sem a Nemzetközi Bíróság ítélete, sem az egyes különvélemények nem említik a ramsari egyezményben részes felek konferenciájának ajánlásait. Ez a hallgatás lehet, hogy pusztán véletlen. Vagy több minden is lehet mögötte?

Részemről hiányérzet támadt nemcsak a hatás jelentőségének a tisztázása, hanem a hatásvizsgálati kötelezettség tartalma tekintetében is. Az esetböl is kiderül (amikor Costa Rica szerint a Nicaragua által készített környezeti hatástanulmány

42 Dugard bíró különvéleménye, 36-45. pontok.

43 Costa Rica v. Nicaragua ügyben hozott ítélet, 172. pont.

44 Resolution VII.16. The Ramsar Convention and Impact Assessment: Strategic, Environmental and Social (1999) 10-14. pontok.

45 Resolution VII.16., 10-14. pontok.

46 SJöstedt, Britta: Costa Rica and Nicaragua before the International Court of Justice: Trying to Work out the Complicated Relationship between Law and the Environment. REICEL, 2013/3, 370. 
nem vizsgálta a kotrási munkáknak a vadvízi élöhelyekre gyakorolt hatását), hogy korántsem mindegy, hogy mikor és milyen tartalommal (milyen környezeti elemekre, tényezőkre kiterjedően) folytatják azt le. Ugyanakkor a Bíróság csak annyit mondott, hogy a környezeti hatásvizsgálat tartalmát mindig a konkrét ügy fényében kell meghatározni, továbbá minden államnak magának kell a belső jogában vagy a beruházást megelőző hatósági eljárásban meghatározni a környezeti hatásvizsgálat speciális tartalmát, tekintettel a beruházás természetére, nagyságára, különféle várható hatásaira. Úgy vélem, hogy itt tökéletes lehetősége lett volna a Bíróságnak választ adni arra a kérdésre, hogy milyen minimumelvárásokat támaszt a nemzetközi jog a környezeti hatásvizsgálat tartalmával kapcsolatban. A Bíróság azonban ezzel a lehetőséggel sem élt, illetve Donoghue bíró különvéleményéböl úgy tünik, hogy nem is fog. ${ }^{47}$

Továbbá a testület annak a kérdésnek a megválaszolása alól is kibújt, hogy létezhet-e kivétel a hatásvizsgálati kötelezettség lefolytatása alól. ${ }^{48} \mathrm{Ez}$ a Nicaragua $v$. Costa Rica ügy kapcsán a szükséghelyzet vonatkozásában merült fel, mivel Costa Rica azt állította, hogy ő szükséghelyzetben volt, ezért nem volt köteles a hatásvizsgálat lefolytatására. A kötelezettség alóli kivétel lehetőségét azonban a Bíróság még csak elméleti jelleggel sem vizsgálta, egyszerüen megállt annak a megállapításánál, hogy Costa Rica nem volt szükséghelyzetben.

A különvéleményekben vitát láthatunk kibontakozni a környezeti hatásvizsgálatnak a természetével, a nemzetközi szokásjogban elfoglalt helyével kapcsolatban. Owada bíró véleménye szerint a környezeti hatásvizsgálat nem egy, az általános nemzetközi jog különálló és független követelménye, hanem fontos eleme annak a kötelezettségnek, miszerint az államoknak megfelelö gondossággal (due diligence) kell eljárniuk annak érdekében, hogy elkerüljék vagy csökkentsék a jelentős határon átterjedő környezeti károkat (sic utere tuo). Tehát a környezeti hatásvizsgálatra technikai jellegủ, holisztikus eszközeként tekint, ami abban segíti az államokat, hogy a környezetre veszélyes tevékenységek várható környezeti hatásainak felmérésével megelőzzék a határon átterjedő károkozást. ${ }^{49}$ Véleménye szerint az ítélet 104. bekezdése lényegében ezt az értelmezést támasztja alá. Ezzel szemben Dugard ad hoc bíró úgy véli, hogy a due diligence az nem maga a kötelezettség, hanem a környezeti hatásvizsgálat lefolytatásának a módjára vonatkozik. Ha ugyanis a due diligence kötelezettségre úgy tekintünk, mint a környezeti hatásvizsgálati kötelezettség forrására, úgy fennáll annak a veszélye, hogy egy állam arra hivatkozva nem alkalmazza a due diligence kötelezettséget a projekt tervezési szakaszában, hogy nem állt fenn károsodás veszélye. ${ }^{50}$ Így véleménye szerint a környezeti hatásvizsgálati eljárás egy önálló kötelezettség. Álláspontom szerint nem sok értelme van ennek a vitának, a lényeg, hogy az államok együttmüködjenek még az olyan esetben is, ahol a határon átterjedő jelentős káros környezeti hatás nem egyértelmüen bizonyítható.

47 Donoghue bíró különvéleménye, 14-15. pontok.

48 Ehhez kapcsolódóan lásd: Bhandari bíró különvéleménye, 43. pont.

49 Owada bíró különvéleménye, 18. pont.

50 Ezzel szemben lásd: Dugard bíró különvéleménye, 9. pont. 
Ami a határon átnyúló károkozást illeti, a Costa Rica v. Nicaragua ügyben a Bíróság szerint Costa Rica nem tudta bizonyítani sem az okozott károkat, sem a kár és károkozó magatartás közötti okozati összefüggést. A Nicaragua v. Costa Rica ügyben már több bizonyíték volt a kár jelentőségének megítéléséhez, így itt már nem (teljesen) a bizonyítottság hiányában döntött a Bíróság, hanem a meglévő bizonyítékok mérlegelésével. Úgy vélem, hogy a jelentős kár megállapításához legközelebb a szedimentáció bizonyításával járt Nicaragua. Itt volt egy pont az ítéletben, amely akár más irányba is terelhette volna a károkozás megítélését. Nicaragua gyakorlatilag azzal érvel, hogy mivel a folyó üledékterheltsége már így is magas, ezért minden további üledékbemosódás, ami az útépítésből származik, az jelentős károkozásnak minősül. Costa Rica szerint azonban, mivel az útépítésből származó üledékbemosódás még Nicaragua számítása szerint sem több mint 2\%-a a folyó teljes terheltségének, így az nem tekinthető jelentős károkozásnak. A Bíróság végül e kérdésben Costa Rica álláspontját fogadta el. Nicaragua ugyanis azt már nem tudta bizonyítani, hogy az útépítésből származó üledékbemosódás hatására a folyóban az üledék mennyisége átlépne egy kritikus szintet. Összességében tehát mégis tudományos bizonytalansággal állt szemben a Bíróság. Vajon nem kellett volna itt is az elővigyázatosság elvét alkalmazni? Ez már az Uruguay folyón épített papírmalom ügyében is felmerült, ami maga után vonta volna a bizonyítási teher megfordulását, de akkor azt a Bíróság elvetette, és továbbra is ragaszkodott a perbeli bizonyítás klasszikus szabályához. ${ }^{51}$ Bruhács János ezzel kapcsolatban már kifejtette aggodalmát. ${ }^{52}$

A fentiekből kitünik, hogy a testület az ítéletben számos kérdést kikerült. Ezen a helyzeten valamelyest enyhített Bhandari bíró különvéleménye, amelyben, miután elismerte, hogy a nemzetközi közjog szánalomra méltó módon hallgat a környezeti hatásvizsgálat kérdéskörében, a környezeti hatásvizsgálat eljárási és tartalmi szabályaival kapcsolatban megfogalmazott javaslataival újabb lépéseket tett, egy a környezeti hatásvizsgálattal kapcsolatos nemzetközi egyezmény megalkotására. Ehhez sok esetben az Espoo-i egyezmény ${ }^{53}$ rendelkezéseit vette alapul, számításba véve azt a tényt is, hogy az mégiscsak egy regionális egyezmény, ugyanakkor számos olyan rendelkezést emelt ki belőle, amely véleménye szerint alapja lehet egy, a tárgyban megalkotott univerzális egyezménynek. Úgy tűnik, hogy Bhandari bíró a környezeti hatásvizsgálattal összefüggő nemzetközi szabályok kidolgozását nem a Bíróság, hanem az államok feladatának tartja. ${ }^{54}$

51 BRUHÁCS: i. m., 46.

52 BRUHÁcs: i. m., 46.

53 Az országhatáron átterjedő környezeti hatások vizsgálatáról szóló, Espooban, 1991. február 26-án elfogadott ENSZ EGB egyezmény. Kihirdette: 148/1999. (X. 13.) Korm. rendelet az országhatáron átterjedő környezeti hatások vizsgálatáról szóló, Espooban (Finnország), 1991. február 26. napján aláírt egyezmény kihirdetéséről.

54 Bhandari bíró különvéleménye, 47. pont. 


\section{Az eset jelentösége}

Az eset jelentőségét véleményem szerint jól kiemeli, ha összevetem az ítélettel kapcsolatos várakozásokat a végeredménnyel. Ennek érdekében, íme néhány részlet a hazai szakirodalomból. Raisz Anikó szerint „egy, a környezetvédelmi indokokat esetlegesen elutasitó, de legalábbis háttérbe szorító itélet [...] hosszú időre visszavethetné a fejlődőben lévő nemzetközi környezetjogot". ${ }^{55}$ Ugyancsak Raisz Anikó írja egy másik cikkében: „álláspontom szerint ugyanakkor a Nemzetközi Bíróság [...] e téren sorsdöntő ítéleteket hoz majd - éspedig nemcsak a perben érintett felek vonatkozásában, hanem saját magára tekintettel is. A nemzetközi környezetjog fejlődése eredményeinek esetleges figyelmen kívül hagyásával ugyanis újult eröre kapnak majd - és egyáltalán nem ok és alap nélkül - az önálló nemzetközi környezetjogi bíróság felállítását célzó törekvések [...]"56 Kecskés Gábor úgy látja, hogy „a Nemzetközi Bíróság akár mérföldkőnek is tekinthetö környezeti tárgyú itélet meghozatala elött áll". ${ }^{57}$

E várakozások dacára az ítélet, úgy gondolom, hogy meghúzódik majd az Uruguay folyón épített papírmalom ügyének árnyékában. Annak ellenére, hogy a vita jellege, a konfliktus szimmetriája, ${ }^{58}$ a környezetvédelmi szokásjog továbbfejlesztésének igénye, mind arra predesztinált, hogy itt a Bíróság valami újat fog mondani..$^{59}$ (Meg kell ugyanakkor jegyezni, hogy a Bíróság elsődlegesen mindig a konkrét jogvita megoldására koncentrál, ${ }^{60}$ így, ha ebből a nézőpontból közelítünk, úgy az ítélettel maguk a felek meg lehetnek elégedve. ${ }^{61} \mathrm{~A}$ testület azonban mind a nemzetközi környezetvédelmi szokásjog, mind a szerződések joga (ramsari egyezmény) értelmezésében és fejlesztésében még csak visszafogottnak ${ }^{62}$ sem mondható, inkább érthetetlenül tartózkodó. Dugard, Bhandari és Owada bírók különvéleményeit olvasva pedig még kontrasztosabban kitűnik ez a hiányosság. Egyszerüen az Uruguay folyón épített papírmalom ügyében már megfogalmazottakat ismételi benne a Bíróság. Úgy tủnik tehát, hogy bár valóban kiváló alkalom lett volna a nemzetközi környezetvédelmi szokásjog fejlesztésére, az eset különlegességét továbbra is az adja majd, hogy a hágai testület ennek az ügynek a vonatkozásában rendelt el először környezetvédelmi érdekből ideiglenes intézkedést, illetve ennek az ügynek

55 RAISZ (2011): i. m., 288.

56 RAISz (2012): i. m., 4.

57 KECSKÉs Gábor: A Nemzetközi Bíróság ítélkezési gyakorlata környezeti tárgyú ügyekben. Állam- és Jogtudomány, 2015/3, 76-77.

58 KECSKÉS: i. m., 77.

59 StePhens, Tim: International Courts and Sustainable Development. In: Brad, Jessup-Kim, Rubenstein (eds.) Environmental Discourses in Public and International Law. Cambridge University Press, Cambridge, 2012, 195-217.

60 OwAdA, Hisashi: International Environmental Law and the International Court of Justice. Iustum, Aequum, Salutare, 2006/3-4, 14.

61 Lásd még Fuentes, Ximena: Latin American States and the International Court of Justice. In: Klein, Natalie (ed.) Litigating International Law Disputes Weighing the Options. Cambridge University Press, Cambridge, 2014, 79-105.

62 VIÑUALES, Jorge E.: The Contribution of the International Court of Justice to the Development of International Environmental Law: A Contemporary Assessment. Fordham International Law Journal, 2008/1, 258. 
a kapcsán kérték elöször az elrendelt ideiglenes intézkedés módosítását. ${ }^{63}$ Sajnos további szomorúságra adhat okot, hogy Nicaragua mégsem állt el a földrészt átszelő csatornaépítés gondolatától. Az előkészítő munkálatokat már megkezdték, csak nem a határ mentén, hanem egy másik, teljesen Nicaragua területén található nyomvonalon. Az új terv kivitelezése várhatóan 2016 végén kezdődik meg, ugyanis eddig a környezeti hatásvizsgálat eredményeire vártak, amely szerint - az előzmények tükrében nem meglepő módon - a megaberuházásnak jelentős környezeti és társadalmi hatásai várhatók. ${ }^{64}$

\begin{abstract}
This article introduces and evaluates the judgment of the International Court of Justice (ICJ) regarding the case concerning certain activities carried out by Nicaragua in the Border Area (Costa Rica v. Nicaragua) proceedings joined with construction of a road in Costa Rica along the San Juan River (Nicaragua v. Costa Rica) from an environmental point of view. The case was one of the latest environmental related affairs before the ICJ and the Hungarian literature had been looking forward with great expectation regarding the Court's award. The conclusion of this essay is that in spite of the nature of the dispute, the symmetry of the conflict and the constant need for the improvement of the general international environmental law, the ICJ missed the opportunity to develop international environmental customary law and the case will stay in the shadow of the ICJ's previous judgement on Pulp Mills on the River Uruguay.
\end{abstract}

63 LamuS: i. m., 464.

$64 \mathrm{http}: / /$ www.theguardian.com/world/2015/nov/27/nicaragua-canal-postponed-chinese-tycoon (2016. 06. 22.). 